Cambridge Journal of Postcolonial Literary Inquiry, 5(2), pp 141-157 April 2018.

(c) Cambridge University Press, 2018 doi:10.1017/pli.2017.57

This is an Open Access article, distributed under the terms of the Creative Commons Attribution-NonCommercial-NoDerivatives licence (http://creativecommons.org/licenses/by-nc-nd/4.0/), which permits non-commercial re-use, distribution, and reproduction in any medium, provided the original work is unaltered and is properly cited. The written permission of Cambridge University Press must be obtained for commercial re-use or in order to create a derivative work.

\title{
"Literature," Theory from the South and the Case of the São Paulo School ${ }^{1}$
}

\author{
Stefan Helgesson
}

\begin{abstract}
With methodological support in Reinhart Koselleck's notion of historical semantics, and an empirical focus on the Brazilian critic Antonio Candido (1918-2017), this article approaches "literature" as a layered concept that will always fail to function as that "plane of equivalence" that Aamir Mufti sees as an outcome of the Orientalist episteme. This failure is historical in the strongest sense; it derives from the condition that "history is never identical with its linguistic registration," as Koselleck puts it. A concept will therefore, throughout its life span, always encompass a combination of persisting and new meanings. In this way, Candido and the São Paulo school of criticism that he was instrumental in forming can be read as a strong instance of "theory from the South" that exploits the malleability of the concept from within its historical situatedness and contributes thereby to the conceptual worlding of literature.
\end{abstract}

Keywords: conceptual history, theory from the South, world literature, Orientalism, Antonio Candido, Aamir Mufti, Reinhart Koselleck

In his recent, important book Forget English!, Aamir Mufti excavates the global history of the modern concept of literature. The extension of that concept, he claims, has a much longer history than world literature scholars tend to think. Contrary to Pascale Casanova's account of the emergence of the world republic of letters, which dates "the entry into international competition of contestants who until then had been prevented from taking part"-Casanova refers here to the world colonized by Europe - to the years after World War II, Mufti points instead to the massive philosophical and philological undertaking by European scholars in the eighteenth and nineteenth centuries. $^{2}$ It is here, he argues, with the formation of Orientalism, that "non-Western

Stefan Helgesson is a professor of English at Stockholm University. His research interests include southern African literature in English and Portuguese, Brazilian literature, postcolonial theory, translation theory, and theories of world literature. He is the author of Transnationalism in Southern African Literature (2009) and is co-editor (with Pieter Vermeulen) of Institutions of World Literature: Writing, Translation, Markets (2015). (Email: stefan.helgesson@english.su.se)

1 I wish to express my deep gratitude to Maria Elisa Cevasco and Roberto Schwarz for their hospitality and intellectual generosity during my visit to São Paulo in 2015. Without their assistance, this article would not have been written. Any weaknesses and misconceptions in the article are of course my sole responsibility.

2 Pascale Casanova, The World Republic of Letters, trans. M. B. DeBevoise (Cambridge: Harvard University Press, 2004), 48. 
textual traditions made their first wholescale entry as literature, sacred and secular, into the international literary space that had emerged in early modern times in Europe as a structure of rivalries between the emerging vernacular traditions." 3 Through a reading of a distinct set of archives, including early Orientalism, Anglophone South Asian literature and (the inevitable) Erich Auerbach, Mufti proceeds to claim that what has been naturalized as "diversity" is really an epochal, globe-encompassing reordering of cultural traditions (including cosmopolitan ones, such as the Indo-Persian ecumene) according to the twin logic of ethno-nationalist indigenization and the eventual consolidation of "English" as the central mediator of literature as well as knowledge.

The extreme level of generality of Mufti's argument, which extrapolates from a circumscribed empirical base (mainly South and West Asia, and Europe), does cause problems for its credibility, but his basic impulse to reroute the contemporary debate on world literature through the epistemic shift around 1800 is sound. "World literature" covers many phenomena these days-not all of them laudable-but one thing it is achieving is a wave of reconsiderations of earlier "pre-theory" moments in intellectual and literary history from our contemporary standpoint. ${ }^{4}$ And rather than remain with Goethe's scattered and unsystematic remarks on world literature, Mufti wisely moves back a step to Herder (among others), whose complicated philosophical legacy has surprisingly far-reaching implications for how literature, language, and culture are being thought and rethought in our "global" era. ${ }^{5}$

I wish to dwell in this article precisely on the historical dimension of the concept of "literature"-specifically, as I soon shall explain, with regard to a Brazilian case. Much of Mufti's argument hinges on the reader's acceptance of a capacious definition of literature, comprising not just secular fiction and poetry, but textual cultures in a wider sense, as well as the philological efforts at systematizing the knowledge of these cultures. This is where Mufti's and Casanova's respective approaches are constitutively different: if Casanova is wanting to trace the emergence of a highly specific international space of contestation that ultimately produces an aesthetic and autonomous notion of literature, Mufti is really concerned with a system of knowledge-Orientalism-that gathers the full range of humanity's textual cultures under its umbrella. These are, to my mind, two significantly different projects. Mufti's central point is that Orientalism produced "literature" as a "plane of equivalence" enabling the comparison of all the world's textual cultures under its universalizing gaze-not that it reserved the term literature for a restricted and prestigious mode of verbal art, supposedly distinct from all didactic, political, philosophical, religious, and commercial purposes, which is rather what Casanova is claiming.

Literature as a plane of equivalence is indeed an intriguing notion, with philosophical roots in Herder. Its epistemological function is to create unity in diversity, or, to phrase this more powerfully, to acknowledge radical difference within the assumed

3 Aamir Mufti, Forget English! Orientalisms and World Literatures (Cambridge: Harvard University Press, 2016), 58.

4 Another example would be Theo D'haen, The Routledge Concise History of World Literature (New York: Routledge, 2012).

5 And Herder, of course, has been given a significant re-reading in John K. Noyes, Herder: Aesthetics against Imperialism (Toronto: Toronto University Press, 2015). 
collectivity of mankind. Mufti is quite correct to identify this as a key problem and figure of thought in the archives of decolonization. Leopold Senghor's attachment to Teilhard de Chardin's notion of "the Civilisation of the Universal," which is ripe for a rereading by world literature scholars, is one prominent example to add to the discussion. ${ }^{6}$ There is, however, a tension in Mufti's argument that speaks directly to my concerns in this article. On the one hand, he sees Orientalism in a Foucauldian vein as a determining episteme established in the nineteenth century through "a massive realignment of the gears of knowledge and culture." " Here, literature functions surreptitiously and irrevocably according to its colonial logic, regardless of any stated intentions among, for instance, anticolonial nationalists in India. His broader concern, therefore, is "with the ways in which contemporary critical thinking unwittingly replicates logics of a longer provenance in the colonial and postcolonial eras" $^{8}$ (emphasis added). And yet, on the other hand, Mufti inserts frequent disclaimers that the consolidation of the episteme is never settled once and for all:

As my analysis of the Orientalizing process in India ... has attempted to show, this is an ongoing and open-ended process, a determinate logic of the late-capitalist world, so that the critique of Orientalism (and world literature) too is best understood as open-ended and ongoing, rather than engaged in and accomplished once and for all. ${ }^{9}$

Mufti never resolves this divergent emphasis on (synchronic) structure and (diachronic) process. Hence, the Orientalist conception of literature is presented as historically constituted and miraculously untouched by history at one and the same time. As an alternative, and with methodological support in Reinhart Koselleck's notion of historical semantics, it is my intention in this article to approach instead "literature" as a layered concept that will always fail to function as a proper "plane of equivalence," explicit or implicit intentions to the contrary notwithstanding. This failure is historical in the strongest sense and derives from the condition that "history is never identical with its linguistic registration," as Koselleck puts it. This means that a concept will, throughout its life span, always encompass "persisting, overlapping, discarded, and new meanings." ${ }^{10}$ It is by cultivating an attentiveness to such semantic layeredness that a reading of "historical singularity" and "structural iterability" becomes possible to combine. ${ }^{11}$ One might postulate that precisely because of the extremities of historical experience, this conceptual instability is particularly critical in societies shaped by colonization, racialization, and cultural domination. Hence, the instability should not be taken lightly, as a carnivalesque free-for-all, but rather as an indication of the epistemological challenge at hand. At stake here, ultimately, is nothing less than the role of critical thinking emanating from what today often is called "the global south." Should we in the transnational and dominantly Anglophone

6 Léopold Sédar Senghor, Liberté 3: Négritude et civilisation de l'universel (Paris: Seuil, 1977).

7 Mufti, Forget English!, 119.

8 Mufti, Forget English!, 248.

9 Mufti, Forget English!, 145.

10 Reinhart Koselleck, Futures Past: On the Semantics of Historical Time, trans. Keith Tribe (Cambridge: MIT Press, 1985), 164, 83.

11 Koselleck, Futures Past, 164. 
field of literary studies be content to assign the archives of criticism in the global south a secondary role as derivative exemplars of what already has been theorized in "Europe," or, for that matter, as mere expressions of a globalized bourgeois class consciousness? This is the direction in which Mufti's argument is pushing us. Or should we reconsider literature as a question that is approached constantly anew within specific historical and linguistic circumstances? Should we, accordingly, see criticism in the South not as a minority sport, but as critically important to the unfolding and unpredictable conceptualization of literature in the world? In that case, it follows that the compromised legacies of Europe-derived epistemologies of literature can be thought of not as an iron cage, but as malleable and incoherent resources for thinking elsewhere and otherwise. I couldn't, quite frankly, even begin to write this article if I didn't believe this to be true. The issue, therefore, is how the inevitable failure of language to achieve a perfect match between word and world-in this instance between "literature" and literature-can most productively be managed, not that there is such a failure to begin with.

In contrapuntal fashion, the bulk of this article will juxtapose Mufti's argument with a body of critical work that is distant from Mufti's concerns-both geographically and historically-yet merits consideration as we progressively put more meat on the bone of our contemporary world literature debate. Brazilian intellectual history is a rich field to mine, always connected to developments elsewhere-particularly Europe and North America-yet at the same time largely unknown beyond Brazil. My case in point should therefore not falsely be taken as a flash in the dark, but on the contrary as one significant moment in a long and wide-ranging Brazilian and Latin American history of literary-critical thinking that predated the emergence of postcolonial studies in the 1980s and 1990s. The anachronism of this juxtaposition is in fact a central point of this article: if the regional circumscription of Mufti's argument is inevitable, this can be offset by introducing counterpoints from other moments, languages, and spaces. This is, conversely, just as important in relation to the Brazilian context, where these matters are easily seen as exclusively Brazilian concerns. Hence, a comparative contrapuntalism might provide some alternative points of orientation in the difficult but urgent world literature debate.

One way to narrate my case could be as follows: based at the University of São Paulo, and with Antonio Candido (1918-2017) as its leading proponent in the post-World War II decades, there emerged a school of criticism that on a broadly materialist and sometimes explicitly Marxist basis revoked what they saw as the anxious provincialism of Brazilian intellectual life-expressed as an obsessive importation of ideas from the "elsewhere" of Europe and North America-and attempted instead to rethink literature from within Brazilian history itself. This inward turn resisted, however, a reading of Brazilian literature as sui generis and positioned it instead in the world-systemic contexts of colonialism and capitalism. The internationally most famous exponent of this group today is Roberto Schwarz, Candido's erstwhile student, but the local São Paulo circle is wider than that, as has been documented by one its members, Maria Elisa Cevasco. ${ }^{12}$ Candido remains, 
nonetheless, a standard reference and pivotal figure in Brazilian intellectual history, and it is mainly to him I will return here. In doing so, I am clearly engaging with a mode of thinking that precedes post-structuralism and postcolonial theory as it formed in the 1980s and nineties. Candido, whose scholarly approach was exceptionally consistent from the 1940s until old age, can be accused of many things: elitism, genderblindness, old-school Enlightenment universalism. His vocabulary, to be sure, was never processed through the arguments and styles of Jacques Derrida, Michel Foucault, or Gayatri Spivak. Yet an engagement with his work never fails to pay off: I find there a subtlety, dialectical suppleness, and not least, argumentative probity that never conceals its motives but invites the reader to a continued conversation.

An article can only achieve so much, but to provide a broad sense of how "literature" is operationalized in his criticism, I proceed in three steps. The first section contextualizes Candido's project within Brazilian intellectual history. The second looks at his approach to Castro Alves, a leading abolitionist and prominent romantic poet, in the seminal Formação da literatura brasileira (1959; "The formation of Brazilian literature"). It may seem idiosyncratic to single out Alves as an example, but in addition to its illustrative function it demonstrates Candido's seldom discussed take on race in Brazilian literature and connects in this way with other, specificially postcolonial, concerns. The third section, finally, discusses one of Candido's strongest instances of "theory from the South," his essay from 1969 on literature and underdevelopment. Throughout, I am attempting to demonstrate that Candido's central innovation was to read the Brazilian sense of lack and belatedness not as a deficiency, nor as an embarrassment that needed to be covered up, but as the very substance of literature in Brazil.

This article positions itself thereby in the contemporary debate in two distinct ways that hopefully suggest constructive modifications of Mufti's genealogical approach to world literature. First, my concern here is precisely with literature as a concept, or rather, with the worlding of the concept of literature, and not with textual circulation. ${ }^{13}$ It is here that Koselleck's notion of Begriffsgeschichte, or conceptual history, can add to the discussion through its emphasis on temporality. "Concepts," writes Koselleck, are "the concentrate of several substantial meanings." ${ }^{\text {"14 }}$ Accordingly,

\begin{abstract}
[t]he signification of a word can be thought separately from that which is signified. Signifier and signified coincide in the concept insofar as the diversity of historical reality and historical experience enter a word such that they can receive their meaning only in this one word, or can be grasped only by this word. A word presents potentialities for meaning; a concept unites within itself a plenitude of meaning. Hence, a concept can possess clarity, but must be ambiguous. (Emphasis added.) ${ }^{15}$
\end{abstract}

The question to be asked, of course, is if such plenitude and ambiguity applies to Candido's approach, and how it could be read. For Koselleck, plenitude and ambiguity are nothing less than indexes of historical time itself, of the constant and

13 See my article on Ngugi for more on this notion: Stefan Helgesson, "Ngugi wa Thiong'o and the Conceptual Worlding of Literature," Anglia 135.1 (2017): 105-21.

14 Koselleck, Futures Past, 84.

15 Koselleck, Futures Past, 84. 
uncontainable juxtaposition of spaces of experience and the horizons of expectation. Quoting Nietzsche, he affirms that "only that which has no history is definable,"16 a striking one-liner that unsettles all hard and fast claims about the global trajectory of the concept of literature. ${ }^{17}$ Candido's position in relation to the concept is, however, ambiguous-he approaches it both as an empty universal and as a historical product.

This leads me to my second point of entry in the world literature debate, namely what Jean and John Comaroff have dubbed "theory from the South." In their book, the Comaroffs focus on the contemporary moment and on how developments in the global south anticipate what is now happening in the "North." 18 Not wanting to reinstate a teleology of historical development, they do so in an ironic spirit; the real objects of their inquiry are the social consequences of a neoliberal world order, and it is on this basis that the Comaroffs themselves become the theorizers. My methodology is different insofar as it focuses on earlier legacies of theory-production in southern locations, specifically literary theory. Here-and not least in the São Paulo case-we can find a body of thought that broaches the South as, in the Comaroffs' phrasing, "a relation, not a thing in and for itself." 19 'm not claiming this to be an original approach, but its historical and archival inclination can, it seems to me, help both to redress the self-referential nature of northerly theory and contribute to a more multisited conception of postcolonialism.

\section{Rethinking Brazil in the Twentieth Century}

Sporting six images on each of two sides in the style of Egyptian hieroglyphics, the sharply rectangular slab of concrete rises some thirty meters above ground. This is the tower at the Praça do relógio, or clock square, in the center of the vast campus of the University of São Paulo (USP), with its images representing different fields of scientific inquiry. At the top of this modernist riff on ancient obelisks, there is indeed a clock, combining thereby its antique allusions with the registration of an ongoing present. So here I am (the year is 2015), at the internationally most recognized university in Latin America, facing a symbolic manifestation of the transfer of intellectual and academic capital to Brazilian soil.

The short history of USP, which was founded in the 1930s, is an object lesson in how centrality and contemporaneity can be wilfully, and successfully, constructed. In its early decades, the university was staffed to a large degree by French scholars (the most famous would be Claude Lévi-Strauss), which profoundly shaped the terms on which São Paulo academics engaged with their disciplines. ${ }^{20}$ And these academics, in turn, would have a decisive influence on subsequent generations of scholars in

16 Koselleck, Futures Past, 84.

17 Even so, a recurring feature of literary criticism in the global south is the rhetorical gesture of evacuating history from "literature," of abstracting it, so as to make the word adaptable to other histories. In Candido's case, we find it for example in a late essay, "O direito à literatura" ("The right to literature"), where he maximizes the definition of literature to include all modes of verbal art, both oral and written. Antonio Candido, Vários escritos (Rio de Janeiro: Ouro sobre azul, 2011), 171-94.

18 Jean and John Comaroff, Theory from the South: Or, How Euro-America Is Evolving Toward Africa (New York: Routledge, 2012).

19 Comaroff and Comaroff, Theory from the South, 47.

20 Maria de Fátima de Paula, "USP e UFRJ: a influência das concepções alemã e francesa em suas fundações,” Tempo Social 14.2 (2002): 147-61. 
Brazil. The symbolism of the Praça do relogio-the aspiration toward centrality and contemporaneity in the local space-seems in other words to carry greater weight than is immediately apparent.

The problem of (re)locating the center in what is understood to be a periphery is an old and familiar one in Brazilian intellectual history. According to Paulo Eduardo Arantes, a prominent USP philosopher and leftist intellectual, the "dialectic of the local and the cosmopolitan" could even be seen as a law governing the "mental evolution" of Brazil. ${ }^{21}$ But if USP enabled a version of contemporaneity in the field of Brazilian knowledge production, including literary criticism, this must-as Arantes reminds us-be understood as a recent chapter in a much longer history. The Brazilian elite in the nineteenth century, after all, was obsessed with "catching up" with modernity as represented most emblematically by Paris. This drama of belatedness and peripherality would, however, be reconsidered and rearticulated throughout the twentieth century as Brazil was transformed into an increasingly successful and uneven industrial economy. Three works in particular contributed to this reorientation of Brazilian self-perception: Gilberto Freyre's Masters and Slaves (Casa grande e senzala, 1933), Sergio Buarque de Holanda's Roots of Brazil (Raízes do Brasil, 1936) and Caio Prado Júnior's Formação do Brasil contemporâneo (1942, "The formation of contemporary Brazil"). A far broader account of Candido's (male) precursors could be given, including not least Machado de Assis (1839-1908), the master of Brazilian realism, the critic Sílvio Romero (1851-1914), whose oeuvre was the topic of Candido's doctoral thesis, and Mário de Andrade (1893-1945), the leading thinker of Brazilian modernism. For my present purposes, however, the three aforementioned works will suffice to sketch out the intellectual mood of Candido's formative years.

Clearly different in ideological orientation, Freyre, Holanda, and Prado Júnior all placed an emphasis on the colonial legacy of Brazil and how it had shaped a society that must be understood on its own terms rather than as an imperfect version of Europe. Freyre was politically conservative, even reactionary, in temperament, but achieved a fundamental reappraisal of the role of African Brazilians (and hence of the institution of slavery) in the shaping of Brazil. If the racist, social-Darwinist discourse of the late nineteenth century had framed the African Brazilians as an impediment to national development, Freyre regarded them through the haze of luso-colonial sentimentality as a vital and positive element in the constitution of Brazil. Holanda tended more toward the liberal camp and produced in Raizes a synthesizing, Weberian analysis of Brazilian modernity, encapsulated in the notion of the "cordial man," whose outgoing personality was matched by an equal degree of moral inconsistency. At the core of Holanda's account lay the claim that the modern bureaucratic state's distinction between the Gemeinschaft and the Gesellschaft had never taken hold in Brazil. Instead, the plantation economy and the relative lack of centralized colonial rule (compared to Spanish America) extended the relationships of the patriarchal, slave-owning family to the level of state politics, resulting in a confusion of individual

21 "caso fosse possível possível estabelecer uma lei geral de nossa evolução mental, ela tomaria forma de uma dialética de localismo e cosmopolitismo": Paulo Eduardo Arantes, O sentimento da dialética na experiência intelectual brasileira (São Paulo: Paz e terra, 1992), 9. 
and national interests and an emphasis on affective bonds rather than rational governmentality. Prado Júnior, finally, complemented both Freyre's and Holanda's reconsiderations of Brazil with a thoroughgoing Marxist analysis of its colonial history. In all three cases, directing the gaze backward to the colonial era was a bold move given the active suppression by the elite of what was easily thought of as a historical embarrassment. The memory of a colonial past (which had ended formally in 1822) was also, after all, a memory of inferiority and dependence.

All of these interventions arose out of a perceived need to make sense of Brazil and its place in the modern world. Such an act of making sense presupposed, moreover, not only that the frameworks of the modern production of knowledge (sociology, anthropology, history, political economy) could be brought to bear on Brazilian material, but also that Brazil presented a riddle to be solved according to the protocols of what we today would call methodological nationalism. ${ }^{22}$ If there was only one thing that all intellectuals of the period could agree on, then it was that the nation constituted the self-evident, if not always ultimate, horizon of their thinking.

This is not to imply that they did so naively. If anything, the point was that the riddle of Brazil called for the active cultivation of new modes of analysis. Holanda openly stated that "[w]e have brought our forms of association, our institutions, and our ideas from distant countries, and though we take pride in maintaining all of them in an often unfavorable and hostile environment, we remain exiles in our own land."23 This experience of exile was what Roots of Brazil sought to alleviate-although Holanda's "we" was exclusionary insofar as he only seriously considers the legacy of white male European descendants in Brazil. This hugely problematic limitation is typical of its time-but within those limits Holanda's study still provides an illuminating analysis of how Brazil's cultural, social, and political landscape took shape through centuries of disorganized colonization.

This is where Antonio Candido comes in. Shaped by the intellectual climate of the 1930s, he studied at USP and would spend his entire academic career there. His ground-breaking study Formação da literatura brasileira: momentos decisivos (1959; "The formation of Brazilian literature: decisive moments") did for literature what Holanda and Prado Junior did for the political and economic history of Brazil. By aiming to write a history of the Brazilians in their very "desire to have a literature" ("uma 'história dos brasileiros no seu desejo de ter uma literatura' "), his starting point is a community he identifies as "Brazilians." ${ }^{24} \mathrm{He}$ is at pains, however, to explain that his interest lies not in literary manifestations - that is, occasional instances of colonial writing-but in how the "Brazilians" eventually shaped a self-sustaining literary system. This central methodological maneuver is what clears the ground for a properly historical understanding of literature as a composite phenomenon. It demonstrates at

22 Ulrich Beck, The Cosmopolitan Vision, trans. Ciaran Cronin (Cambridge: Polity, 2006).

23 Sérgio Buarque de Holanda, Roots of Brazil, trans. G. Harvey Summ (Notre Dame, IN: University of Notre Dame Press, 2012), 1. “Trazendo de países distantes nossas formas de convívio, nossas instituições, nossas ideias, e timbrando em manter tudo isso em ambiente muitas vezes desfavorável e hostil, somos ainda hoje uns desterrados em nossa terra": Sérgio Buarque de Holanda, Raízes do Brasil (São Paulo: Companhia das letras, 2014 [1936]), 35.

24 Antonio Candido, Formação da literatura brasileira: momentos decisivos, 13th ed. (Rio de Janeiro: Ouro sobre azul, 2012 [1959]), 27. 
the same time how Candido is prepared to re-semanticize the concept. Literary autonomy is for him not the new critical autonomy of the individual, free-floating text, but the autonomy of the system of writers, publishers, readers, critics, and texts as a dynamic whole. But-and this is crucial-nor is he content with the reduction of the literary text to its external conditions of production. It is instead the interaction of the different constitutive elements of the literary system that interests him, and that results in the subtitle's "decisive moments," when allegiances, values, and poetics shift. Candido himself is in fact a masterful close reader, but he reads in order to grasp the text's social dimension.

This begins to show how the Comaroffs' recent notion of "theory from the South" is an older phenomenon if we take it to mean an intellectual formation that takes shape within and in response to historical conditions in a given colonial or postcolonial setting. If it does or does not prefigure developments or thinking in the North is beside the point, even though one could claim that Candido's carefully balanced notion of the literary system anticipates Bourdieu's sociology of literature by decades. More importantly, Candido's theoretical intervention in 1950s occurred just as Brazil was experiencing a remarkable cultural upswing that soon, with the military coup in 1964, would be compelled to become a culture of resistance. Cevasco speaks of the formation of a "cultural Left," in which she includes "cinema novo, Paulo Freire's pedagogy of the oppressed, and popular music, as bossa nova met the samba at the favelas." ${ }^{25}$ Candido's own relationship with popular culture would always remain ambivalent, but it is no exaggeration to claim that his innovative sociology of literature was instrumental in fostering a distinct and vibrant mode of socially oriented literary studies at USP, which would eventually also produce its own journal, Literatura $e$ sociedade, today a premier academic review in Brazil.

\section{Castro Alves}

When accounting for the literary system as it evolved in the eighteenth and nineteenth centuries, Candido consistently views Brazilian literature as a postEuropean affair. He demonstrates not only how European the neoclassicists were in their training and outlook, but also how the romantic turn was mediated via Europe, mainly France, but also Portugal, Germany, and England. The French bias meant that romanticism was "belated," but the impact of Madame de Staël and Chateaubriand, as well as the Portuguese writer Almeida Garrett, was profound and would have far-reaching consequences in independent Brazil. What is of interest here is how Candido historicizes this literary and aesthetic development. Or to use another vocabulary: he demonstrates some of the colonial and postcolonial twists of Brazilian romanticism, leading gradually to increasing differences between the substantive meaning of "literature" in Brazil and in France.

Formação is a vast and specialized study, so my discussion here is necessarily selective and conditioned by points of particular interest to readers outside of Brazil. In this regard, two crucial indices of the semantic rift in literature as a concept are indianismo, or Brazil's own version of nativism, and the poetry of slavery and 
abolitionism. Both are articulated from a middle-class "white" perspective, but their trajectories and motivations are significantly different. If the indianismo of Gonçalves Dias and José de Alencar in the 1850s and 1860s could be seen as little more than a "compensatory sentiment," a projection of a creole desire for national authenticity that sentimentalized the indio and elided the violence of colonial conquest, the ubiquitous presence of African slaves was a fraught issue. ${ }^{26}$ First-nation Brazilians were, according to Candido, virtually absent from the cities and therefore almost mythological in the eyes of the writers. The literary appropriation of the indio was also sanctioned by the European authority of Chateaubriand, whose Atala (1801) provided a blueprint for precisely such a mythological projection. ${ }^{27}$ This made it easy to transform the indio into a "touchstone of patriotic pride." The African slaves, by contrast, were integrated into daily life and therefore difficult to "elevate to an aesthetic object within a literature ideologically tied to a caste structure [estrutura de castas]." ${ }^{28}$ A late romanticist, Antonio de Castro Alves managed, however, more than any other poet to bring the figure of the slave and the African into the ambit of Brazil's white writing. ${ }^{29}$ In sharp contrast to Alencar, who defended slavery, Alves attacked it relentlessly. Candido describes his ability to do so in poetry as a "literary miracle," given that it challenged the powerful urge among the middle class to suppress their mixed heritage by simply ignoring or camouflaging the African presence not just in Brazil, but in themselves. ${ }^{30}$ A darker complexion, he explains, could be attributed with pride to an "Indian" ancestor in order not to confront a slave heritage. The literary transformation of the black character into a hero was therefore a significant changeover that nonetheless remained marked by racial anxieties. Before Alves, in order to make a black slave a hero, he or she had to be whitened. The idealized slave was typically of mixed heritage, making him or her possible to "contain within the bounds of white sensibility," and thereby position him or her within the affective register of the bourgeoisie. ${ }^{31}$

Interestingly, if indianismo was an offshoot of French romanticism, Candido argues that above all Castro Alves's slave poetry derived from a rhetoric of humanitarianism, which enjoyed a high moment in the mid-nineteenth centuryevident, for example, in the ineffectual banning of the slave trade (not slavery) in 1850. The purification of lyric and an inward turn were in other words not the only results of romanticism. This long era also engaged a social and public verbal practice that intensified in the politically dramatic decade of the 1860s. Even if Candido at one point characterizes this rhetorical turn as an outcome of "typically Brazilian verbal

26 Candido, Formação da literatura brasileira, 590.

27 And Chateaubriand himself drew inspiration from, among other thing, early French travel writing on the Americas, such as Jean-Baptiste Du Tertre's L'Histoire générale des Antilles habitées par les François (1667-1671).

28 Candido, Formação da literatura brasileira, 589.

29 This could be compared to the role of Thomas Pringle's poetry written during and after his sojourn in the Cape Colony. Pringle was earlier by several decades, however, and a driving force in Scottish abolitionism.

30 Candido, Formação da literatura brasileira, 590.

31 "Assim, os protagonistas de romances e poemas, quando escravos, são ordinariamente mulatos a fim de que o autor possa dar-lhes traços brancos e, deste modo encaixá-los no padrões da sensibilidade branca." Candido, Formação da literatura brasileira, 590. 
incontinence," the more important observation is that the 1860s saw the emergence in Brazil of a vibrant daily press and outspoken advocates of democracy-in brief, of a public sphere in the Habermasian sense of the word. ${ }^{32}$ In its successful literary moments, the synthesis of romanticism and rhetoric resulted in a stirring abolitionist poem such as Alves's "O navio negreiro" (1869, "The Slave Ship"), which combined sonorous cadences, the romantic sublime-the infinity of sky and sea, the depth of suffering-and emotional outpourings with a social appeal. Underlying such poetry is a dialectic of man against society, of master and slave, which in Candido's reading ultimately subsumes the historicity of slavery by inserting it into the drama of "human destiny" and drawing in this way on messianic tendencies in romanticism. A skeptical reading of such recoding of slavery could see it as a way to evade, or at least attenuate, White accountability. And it is by the same token evident how the humanitarian pathos of stanzas such as these from "The Slave Ship," where conspicuous ellipses flaunt how the horror of slavery exceeds the poem's linguistic grasp, is dependent for its effect on a White racializing gaze:

Era um sonho dantesco ... o tombadilho

Que das luzernas avermelha o brilho.

Em sangue a se banhar.

Tinir de ferros ... estalar do açoite ...

Legiões de homens negros como a noite,

Horrendos a dançar...

Negras mulheres, suspendendo às tetas

Magras crianças, cujas bocas pretas

Rega o sangue das mães:

Outras môças ... mas nuas, espantadas,

No turbilhão de espectros arrastadas,

Em ânsia e mágoa vãs.

E ri-se a orquestra, irônica, estridente ...

E da ronda fantástica a serpente

Faz doudas espirais ...

Se o velho arqueja ... se no chão resvala,

Ouvem-se gritos ... o chicote estala.

E voam mais e mais... ${ }^{33}$

(As in a vision of Dante,

I saw the quarterdeck, slippery with blood,

The skylight washed with crimson.

The clanking irons . .. the crack of a whip ...

32 Candido, Formação da literatura brasileira, 585.

33 Antonio de Castro Alves, "O navio negreiro-tragédia no mar," in Obra completa (Rio de Janeiro: José de Aguilar, 1960), 280. 
Legions of men black as the night,

Dancing their horrible death-dance . . .

Black-mouthed and listless children

Hang at their black mothers' exhausted breasts

Spattered with blood

Shivering and naked girls,

A crowd of ghosts dragging

Their wretched bodies . . .

The ironic chorus laughs at itself

As the dark serpent coils

Its mad and spiraling dance... .

If an old man gasps for breath ... falls to the ground,

There are screams, the cracking of whips ...

And their feet move on and on ....)

The enduring point, nonetheless, is that what Candido identifies as the romantic crisis of representation in Brazilian poetry is exacerbated by its thematic turn to the social reality of slavery. Slavery, after all, is being addressed by Alves (and Fagundes Varela and others), even though he inherits a conception of literature in which contemporary slavery and African subjects simply have no place. His occasional ventriloquizing of African voices and his poetic projections of African landscapes are precisely romantic in the pejorative sense of the word-imaginative, freewheeling, sentimental. But even so, the rupture with literary convention is palpable and ultimately as formal as it is thematic. Alves-and this is an extension of Candido's argument-transforms in "The Slave Ship" the romantic sublime into an encoding of what might be called a trans-Atlantic sublime, under the aegis of colonialism and capitalism, with the worldsystem metonymically and allegorically condensed to the slave ship, where French, English, and Italian mariners share the same space as the slaves they torture and who recall their freedom in "Sierra Leone."

"O navio negreiro" can in this way be read as a privileged textual node that helps us to specify the overall tendency of Candido's historical account: it is those moments where topic, form, and the public sphere connect and disrupt one another that are the "decisive moments" in the formation of literature. The connection and disruptionboth need to be considered simultaneously_can be understood, in Koselleck's sense, as versions of the contemporaneity of the noncontemporaneous. There is no empty, homogeneous temporality here, in Benedict Anderson's sense of the imagined community: literary forms accumulate their own temporality, including the gradual emergence of a local tradition, which is so important to Candido's understanding of the literary system. ${ }^{35}$ But social and political time (in this instance slavery and

34 Antonio de Castro Alves, "Tragedy at Sea: The Slave Ship," in The Major Abolitionist Poems, ed. and trans. Amy A. Peterson (New York: Garland, 1990), 15-17. It should be noted that this is a domesticating translation that smoothens the syntax and disambiguates Alves's elusive imagery.

35 Benedict Anderson, Imagined Communities: Reflection on the Origins of Nationalism (London: Verso, 1983). 
abolitionism) will likewise intervene in the literary realm, regularly producing aesthetic crises that affect the scope and meaning of literature.

\section{Literature and Underdevelopment}

If the perennial dilemma of Brazil had been understood as a lack of a consistent and gradually developing local tradition, it is the unfolding history of the lack that is central to Candido's account. In Formação, he famously lamented: "Compared to the great literatures, ours is impoverished and weak. But it is this literature, and not any other, that expresses who we are. If it is not loved, it will not disclose its message."36 Put differently, it is the temporal deficit of "incompleteness" and "backwardness" that intrigues Candido insofar as it is this that is resolutely local and advances the deeper understanding of Brazilian literature as produced through a history of entanglement with Europe. This is provocative given what postcolonial theory has taught us about conceptions of belatedness and prefabricated narratives of historical progress. ${ }^{37}$ Yet, once again, Candido puts an unexpected spin on this figure of thought.

"Literature and Underdevelopment," perhaps his best-known essay, provides a sharp consideration of the temporal deficit, written at the height of repression in Brazil in 1969. Here it is the contemporary condition of possibility for literature in Brazil as well as Latin America generally that is in focus, and the argument is directly relevant to constructions of theory from the South. The instructiveness of the essay in relation to Formação lies in its focus not on national autonomy that aims at transcending colonial dependency but rather on the world-systemic predicament known as "underdevelopment." Building on a discussion initiated by Mário Vieira de Mello, he notes that the content of Brazilian futurity began to transform (once again) in the 1930s. If the dominant narrative until then had framed Brazil, optimistically, as "the new country" that hadn't yet come into its own but possessed a glorious future, an increasingly influential sense of underdevelopment emerged from the 1940s onward. According to the temporal structure of underdevelopment, the future would not entail transcendence but only-at best-an evening out of differences with the "advanced world." This can seem to contradict the successes of Brazilian modernity and modernism in the 1950s and sixties-we could refer here to Oscar Niemeyer's Brasília, bossa nova, or the novels of João Guimarães Rosa and Clarice Lispector. However, it needs to be read as an attempt at tracing retrospectively a subtle shift that could help to account for the reactionary political turn of the 1960s, which replaced the optimism of populist democracy with the nihilism of capitalist growth under authoritarian rule. Candido registers the shift through its national and regional effects, but it had of course world-historical dimensions: "development" and "underdevelopment" became hegemonic terms in international relations post-1945. This was, in other words, a point at which Candido's concerns and those of decolonization met.

Underdevelopment was not exclusively detrimental, in his view. If the millennarianism of the previous "country of the future" paradigm was a fantasy that

36 Candido, Formação da literatura brasileira, 11.

37 Comaroff and Comaroff, Theory from the South, 11-12. See also Dipesh Chakrabarty's Provincializing Europe: Postcolonial Thought and Historical Difference (Princeton, NJ: Princeton University Press, 2000). 
compensated for the impoverished grandeur of Brazil ("In America everything is great, only man is small"), the sense of underdevelopment could lead to a focused attempt at tackling fundamental inequalities in Brazilian society. ${ }^{38}$ Indeed, this is where Candido himself for the first time (to my knowledge) fully addresses the problem of illiteracy as an index of Brazilian and Latin American "backwardness":

In fact, illiteracy is linked to the manifestations of cultural weakness: lack of the means of communication and diffusion (publishers, libraries, magazines, newspapers); the nonexistence, dispersion, and weakness of publics disposed to literature, due to the small number of real readers (many fewer than the already small number of literates); the impossibility, for writers, of specializing in their literary jobs, generally therefore realized as marginal, or even amateur, tasks; the lack of resistance of discrimination in the face of external influences and pressures. The picture of this weakness is completed by such economic and political factors as insufficient levels of remuneration and the financial anarchy of governments, coupled with inept or criminally disinterested educational policies. ${ }^{39}$

This is dated thinking-Candido is blind here to the enabling and creative qualities of popular culture-but let us remain for a moment with his own terms of engagement. If illiteracy is a general feature of underdevelopment, Latin America differs from other "underdeveloped" regions insofar as two European languages are widely spoken on the continent-languages connected, moreover, to two of the few "underdeveloped" countries in Europe, Portugal and Spain. This is the first time that Candido places Brazil and Latin America in a comparative "third world" framework, which is a strong indication that the paradigm of underdevelopment entailed a reconfiguration of the global imaginary also in Brazil post-1945. This prompts Candido to compare the predicament of Latin American writers with that of Léopold Senghor and Chinua Achebe, who are "doubly separated from their potential publics" given that they are read only in the West or by an "incredibly reduced" local public. ${ }^{40}$ In Latin America, he claims, the potential audience for literature in Portuguese and Spanish is vast. Even so, Candido predicts a bleak future for "erudite literature": the masses, he says, are embroiled in folkloric culture and oral communication, exchanging rural folklore with the urban folklore of mass culture once they move to the city. His argument is directed with particular vigor against commodified "mass culture," which can seem quaint in our day. But his reasons for doing so have a clear political grounding. "[T]here is no

38 Antonio Candido, "Literature and Underdevelopment," in On Literature and Society, ed. and trans. Howard S. Becker (Princeton, NJ: Princeton University Press, 1995), 120.

39 Candido, "Literature and Underdevelopment," 121-22. "Com efeito, ligam-se ao analfabetismo as manifestações de debilidade cultural: falta de meios de comunicação e difusão (editoras, bibliotecas, revistas, jornais); inexistência, dispersão e fraqueza dos públicos disponíveis para a literatura, devido ao pequeno número de leitores reais (muito menor que o número já reduzido de alfabetizados); impossibilidade de especialização dos escritores em suas tarefas literárias, geralmente realizadas como tarefas marginais ou mesmo amadorísticas; falta de resistência ou discriminação em face de influências e pressôes externas. O quadro dessa debilidade se completa por fatores de ordem econômica e política, como os níveis insuficientes de remuneração e a anarquia financeira dos governos, articulados com políticas educacionais ineptas ou criminosamente desinteressadas": Antonio Candido, "Literatura e subdesenvolvimento," in Educação pela noite (Rio de Janeiro: Ouro sobre azul, 2011), 172.

40 Candido, "Literature and Underdevelopment," 123; Candido, "Literatura e subdesenvolvimento," 174. 
point," he writes, "for the literary expression of Latin America, in moving from the aristocratic segregation of the era of oligarchies to the orchestrated manipulation of the masses in an era of propaganda and total imperialism." ${ }^{41}$

The Enlightenment aspect of Candido's thinking is apparent here, as elsewhere in his essays, but we must not ignore that it is accompanied by a critical view of the Enlightenment legacy. The "aristocratic segregation" of which he speaks above is precisely what he accuses versions of Enlightenment thought to have perpetuated under camouflage in Latin America. With Brazil's Pedro II and the Ateneo group in Venezuela as notable examples, a cult developed around not just education but also, specifically, the printed word. Castro Alves even imagined "America" to be the true homeland of print. His poem "O livro e a America" ("The Book and America") linked Gutenberg's invention of print technology to Columbus's voyage. ${ }^{42}$ Through a rhetorical sleight of hand, Alves attempted thereby to cast the imagined glorious future of America as a historical necessity with literature as its catalyst. In Candido's reading, this was little more than a disavowal of the real and conflicted conditions governing the work of writers. In actual fact, the literary output of Latin America has largely been written for an imagined ideal audience in Europe (notably France). In wording that anticipates Pascale Casanova by several decades, he speaks of writers having produced "false jewels unmasked by time, much contraband that gave them an air of competitors for some international prize for beautiful writing." In this way, Candido underlines the uneven and layered aesthetic temporality of the republic of letters:

\begin{abstract}
All literature presents aspects of backwardness that are normal in their way, it being possible to say that the average production of a given moment is already tributary to the past, while the vanguard prepares the future. Beyond this there is an official subliterature, marginal and provincial, generally expressed through the Academies. But what demands attention in Latin America is the way aesthetically anachronistic works were considered valid; or the way secondary works were welcomed by the best critical opinion and lasted for more than a generation-while either should soon have been put in its proper place, as something valueless or the evidence of a harmless survival. (Translation modified.) ${ }^{43}$
\end{abstract}

Candido parts ways with the later model of Casanova in his emphasis on locally grounded legitimacy rather than international rivalry. Anachronism may in fact be perfectly legitimate, as he says with reference to the extended life of naturalism in Brazil. Indeed, this type of legitimacy is the only durable antidote to the extroverted

41 Candido, "Literature and Underdevelopment," 125. "E não há interesse, para a expressão literária da América Latina, em passar da segregação aristocrática da era das oligarquias para a manipulação dirigida das massas, na era da propaganda e do imperialismo total": Candido, "Literatura e subdesenvolvimento," 176. 42 Castro Alves, "O livro e a América," in Obra completa, 76-78.

43 Candido, "Literature and Underdevelopment," 128. "Toda literatura apresenta aspectos de retardamento que são normais ao seu modo, podendo-se dizer que a média da produção num dado instante já é tributária do passado, enquanto av vanguardas preparam o futuro. Além disso, há uma subliteratura oficial, marginal e provinciana, geralmente expressa pelas Academias. Mas o que chama a atenção na América Latina é o fato de obras secundárias serem acolhidas pela melhor opinião crítica e durarem por mais de uma geração-quando umas e outras deveriam ter sido desde logo postas no devido lugar, como coisa sem valor ou manifestação de sobrevivência inócua": Candido, "Literatura e subdesenvolvimento," $180-81$. 
predicament of Latin American literature, which the successes of contemporary writers testify to: Jorge Luis Borges, Mário Vargas Llosa, Júlio Cortázar, Juan Rulfo, João Guimarães Rosa, Clarice Lispector. Here, Candido is at one with the moment of the Latin American "boom," but not as a translational phenomemon produced in North America. Instead, what he sees in these writers is a reconfiguration of the aesthetic field that takes the inherent anachronisms of Latin America as its substance and point of departure rather than anxiously locate the center of aesthetic gravity elsewhere, in Paris or New York. Of course, such an account needs to be tempered with the reminder that each of the aforementioned writers (with the exception of Rulfo) led peripatetic, "cosmopolitan" lives with long sojourns in Europe and North America. Even so, one could convincingly argue in support of Candido that we witness in these cases an outcome of what Arantes identified as the dialectic of the local and the cosmopolitan that both favored and transformed the local vernacular pole. In the context of "underdevelopment," writers from the "developed" strata of Latin American societies achieved in other words an enduring connection with the full "combined and uneven" panorama of their life-worlds. ${ }^{44}$

\section{Coda}

A fuller understanding of what I have called the São Paulo school would require an engagement with the entire panorama of the Brazilian literary field-not least the peculiar rivalry between São Paulo and Rio de Janeiro. The São Paulo critics are also nationally located polemicists, as for instance Schwarz's digs at Afrânio Coutinho and Haroldo de Campos demonstrate. ${ }^{45}$ But my purpose has been more restricted. I have wanted to show how Antonio Candido analyzes the shifting semantics of "literature" in Brazil and how his own take on literature develops in the period between Formação and "Literature and Underdevelopment." In this way, I have wanted to carve out a sounding board for some current articulations of the fault line between postcolonial and world literary studies. As should be evident by now, Candido entertains both thin and thick conceptions of literature, both aesthetic and historical, both "universal" and "national" as he phrases it himself. This is not so much an aporia as a precise indication of the multiple temporality and polysemy of the concept. Examining instantiations of "literature" is, I have argued, an effective way to move beyond the stalemate between postcolonialism and world literature because it takes semantic instability as its object of study. Literature, in other words, is not a "plane of equivalence" but rather a site of contestation.

If I expressed an initial dissatisfaction with the contradiction between structure and process in Aamir Mufti's Forget English!, my discussion has hopefully demonstrated a more flexible mode of reading-located both in Antonio Candido's work and in my take on Candido. Candido cannot just be valorized offhand nor transplanted wholesale to other settings in the "South." But this is precisely the point. If a cluster of insistent questions in literary studies today revolve around the enabling potential

44 I'm drawing here on the work of the Warwick Research Collective, Combined and Uneven Development: Towards a New Theory of World-Literature (Liverpool, England: Liverpool University Press, 2015).

45 Schwarz, Sequências brasileiras (São Paulo: Companhia das letras, 1999), 60-63. 
(or lack thereof) of "world literature," then Candido can help us to see why those questions require constantly new answers that refrain from skirting the density of local literary histories but, on the contrary, understands this density to be the very substance through which world literature can be thought. Literature is as inescapably historical as colonialism and capitalist globalization. Understanding how its meaning sediments and transforms historically should therefore be a primary goal of world literature studies, a task that can only be tackled successfully if the longer histories of critical thinking on literature in the "global south" are taken on board. By enabling us to grasp the historicity of aesthetic validity, Candido provides us with an impetus for moving forward on that particular road. 